\title{
Kinetic and Isotherm Studies on Ciprofloxacin an Adsorption using Magnesium Oxide Nanopartices
}

\author{
Nahid Khoshnamvand ${ }^{1}$, Shahin Ahmadi ${ }^{2 *}$, Ferdos Kord Mostafapour ${ }^{3}$ \\ ${ }^{1}$ Department of Environmental Health, Lorestan University of Medical Sciences, Lorestan, Iran. \\ ${ }^{2}$ Department of Environmental Health, zabol University of Medical Sciences, zabol, Iran. \\ ${ }^{3}$ Department of Environmental Health, zahedan University of Medical Sciences, zahedan, Iran.
}

\begin{tabular}{|c|c|}
\hline ARTICLE INFO & ABSTRACT \\
\hline Article history: & \multirow{8}{*}{$\begin{array}{l}\text { The antibiotics along with the sewage, pharmaceutical industries water waste, veterinary clinics and hospital } \\
\text { sewages and the agricultural products noticeably enter into the water resources and the environment. The } \\
\text { objective of this study was to investigate ciprofloxacin removal efficiency from aqueous solutions by using } \\
\text { Magnesium Oxide nanoparticles }(\mathrm{MgO}) \text {. The effects of } \mathrm{pH} \text {, nanoparticles dose, contact time, initial antibiotic } \\
\text { concentration were assessed on ciprofloxacin removal efficiency in laboratory. Under optimal conditions of } \\
\text { concentration, the removal efficiency was } 85 \% \text {. and } \mathrm{q}_{\mathrm{m}} \text { of the } \mathrm{MgO} \text { nanoparticles was } 3.46 \mathrm{mg} / \mathrm{g} \text {. The process of } \\
\text { ciprofloxacin adsorption on } \mathrm{MgO} \text { nanoparticles was depended on Langmuir adsorption isotherm more than other } \\
\text { isotherms. Batch kinetic experiments showed that the adsorption followed Pseudo second -order kinetic model } \\
\text { with correlation coefficients greater than } 0.978 \text {. }\end{array}$} \\
\hline Received on: 20/09/2017 & \\
\hline Accepted on: 07/11/2017 & \\
\hline Available online: $30 / 11 / 2017$ & \\
\hline Key words: & \\
\hline Magnesium Oxide & \\
\hline nanoparticle, Adsorption, & \\
\hline $\begin{array}{l}\text { Ciprofloxacin, Isotherm, } \\
\text { kinetic. }\end{array}$ & \\
\hline
\end{tabular}

\section{INTRODUCTION}

Fluoroquinolones are an important class of irresolvable antibiotics used for human beings and animals (Andreozzi et al., 2005). The increase of fluoroquinolones concentration in ecosystem results to bacterial resistance and chromosomal mutation (Andreozzi et al., 2005; Ji et al., 2014). The ciprofloxacin (CIP) is one the antibiotics of fluoroquinolone class used widely in the treatment of urinary, digestive and respiratory systems with good results (Wu et al., 2013; Ikehata et al., 2006). One of the main reasons for antibiotics purification is bacterial resistance, which is a major threat to human health (Ji et al., 2014). So far, the methods applied for CIP elimination are ozonation (Ikehata et al., 2006; Ahmadi, 2017a) oxidation (Jiantuan et al., 2004), coagulation (Kord Mostafapour et al., 2017) and adsorption (Zhang et al., 2011).

\footnotetext{
* Corresponding Author

Email: sh.ahmadi398 @ gmail.com
}

One of the main methods is adsorption. The adsorption process is applied widely in industry for eliminating the organic pollutants. The highly used adsorbing materials are the active granulated carbons, but they are very expensive and will be hardly revived (Liao et al., 2011; Ahmadi; 2017b). Nanoparticles are a suitable option because of their large surface in order to complete chemical reactions and adsorption of organic compounds (Tajbakhsh et al., 2014).

Magnesium oxide nanoparticles $(\mathrm{MgO})$ are a basic oxides group and provided a large range of application in adsorption process (Tajbakhsh et al., 2014; Kermani, 2013). The important characteristics of $\mathrm{MgO}$ nanoparticles are availability, cheap, nonvolatile, non-toxic, stability, adsorption capacity and high reactivity (Kermani et al., 2013). It was used as a catalyst in the purification of dangerous, anti-bacterial and resistive materials (Nga et al., 2013). The main purpose of this study was the investigation of magnesium oxide nanoparticles efficiency in the removal of CIP from aqueous solution. 
The impact of various factors such as the contact time, adsorbent dosage, $\mathrm{pH}$ and initial concentration of CIP were studied to determine the optimum condition. The determination of these optimum conditions will cause the enhancement of the efficiency of $\mathrm{MgO}$ nanoparticles in CIP removing. Finally, the adsorption isotherm and kinetic models have been studied.

\section{MATERIALS AND METHODS}

\section{Materials}

The ciprofloxacin (CIP) with molecular weight $331.35 \mathrm{~g}$ $\mathrm{mol}^{-1}$ from Merck Company (Germany) was purchased. The stock of CIP with a concentration of $1000 \mathrm{mg} / \mathrm{L}$ was prepared in distilled water. The chemical structure of CIP is shown in Fig.1. Magnesium oxide $(\mathrm{MgO})$ nanoparticles were purchased from Sigma Co. (US) with a diameter of less than $50 \mathrm{~nm}$, purity of $98 \%$ and the effective area of $1236 \mathrm{~m}^{2} / \mathrm{g}$. To determine the exact diameter of the nanoparticle, SEM (HITACHI Model S-3000 H) provided some information about the morphology of adsorbent surface. TEM (FEI Tecnai G2 20 S-TWIN) was used to measure the diameter of nanoparticles.

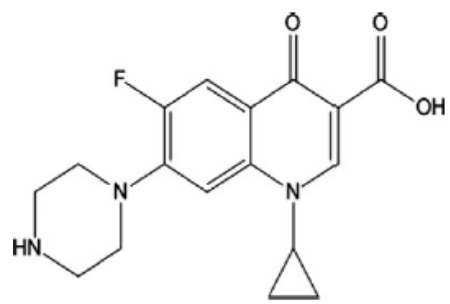

Fig. 1: The chemical structure of CIP.

\section{Batch adsorption experiments}

The effect of $\mathrm{MgO}$ nanoparticles (0. 1, 0. 3, 0.4, 0.5, 0.8 and $1 \mathrm{~g} / \mathrm{L})$, contact time $(15,30,45,60,75,90$ and $120 \mathrm{~min}), \mathrm{pH}$ $(2,3,6,9$ and 11) and CIP concentrations of 10 to $250 \mathrm{mg} / \mathrm{L}$ on CIP removal was investigated. The $\mathrm{pH}$ of the water sample was adjusted by adding $0.1 \mathrm{~N} \mathrm{HCl}$ or $0.1 \mathrm{~N} \mathrm{NaOH}$ solutions. The initial and final CIP concentrations remaining in solutions were analyzed by a UV-visible recording spectrophotometer was determined at a wavelength of maximum absorbance $\lambda_{\max }=276 \mathrm{~nm}$ (Kord Mostafapour et al, 2016; Ahmadi-b et al., 2017). There are many isotherm models for experimental data analysis and description of equilibrium in adsorption such as Langmuir, Freundlich, and Tempkin (Kord Mostafapour et al, 2016). Synthetic equations were used to evaluate the behavior of transferring molecules of adsorbate material in time and the effective variables on reaction rate (Ahmadi-c et al., 2017). In this study, the Pseudo first order, Pseudo-second-order and Elovich models were used to evaluate the adsorption process of CIP on the nanoparticle. The equation adsorption kinetics and isotherms are shown in Table1 (Abramović et al., 2013).

Removal and sorption capacity of the studied parameters from CIP was calculated based on the following formula (Ahmadid et al., 2017):

$$
\% R=\frac{\left(C_{0}-C_{f}\right)}{C_{0}} 100(1) \quad q_{e}=\frac{\left(C_{0}-C_{e}\right) V}{M}
$$

Where, $\mathrm{C}_{0}$ and $\mathrm{C}_{\mathrm{f}}$ are the initial and final. $\mathrm{C}_{\mathrm{e}}$ is equilibrium concentration (mg/L) of CIP, M weight of adsorbent (g) and V (L) is the volume of the solution.

\section{RESULTS AND DISCUSSION}

Figs. 2 and 3 display the SEM and TEM images of $\mathrm{MgO}$ nanoparticles respectively. For, the special level was equal to 1236 $\mathrm{m} / \mathrm{g}$ indicating a suitable special level.

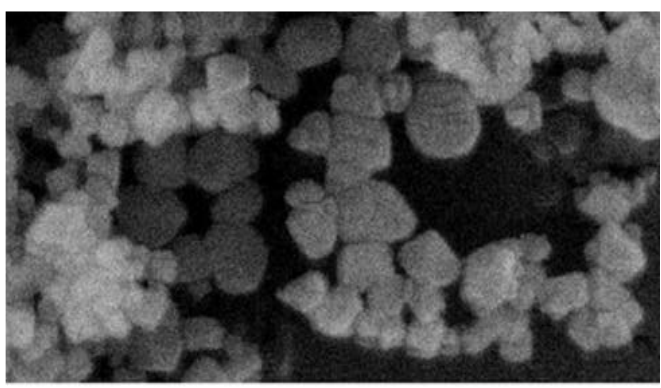

Fig. 2: SEM image on $\mathrm{MgO}$ nanoparticles.

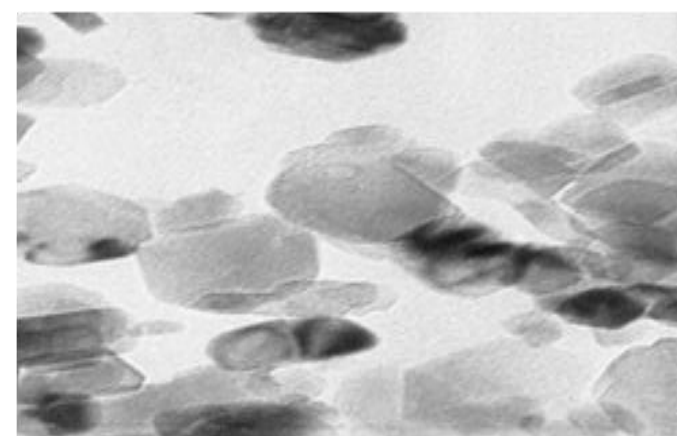

Fig. 3: TEM image on $\mathrm{MgO}$ nanoparticles.

Table 1: The equations of isotherms and kinetic.

\begin{tabular}{|c|c|c|c|}
\hline \multirow{3}{*}{ Model } & \multicolumn{3}{|c|}{ isotherms } \\
\hline & Langmuir & Freundlich & \multirow{2}{*}{$\frac{\text { Tempkin }}{q_{e}=B_{1} \operatorname{Ln}\left(A_{T}\right)+B_{1} \operatorname{In}\left(C_{e}\right)}$} \\
\hline & $\frac{c e}{q_{e}}=\frac{1}{q_{m}}+\frac{1}{q_{m} K_{l}}$ & $\log q_{e}=\frac{1}{n} \log C_{e}+\log k_{f}$ & \\
\hline \multirow[t]{3}{*}{ Model } & \multicolumn{3}{|c|}{ kinetics } \\
\hline & Pseudo first order & Pseudo second order & Elovich \\
\hline & $\log \left(q_{e}-q_{t}\right)=\log \left(q_{e}\right)-\frac{k_{1}}{2.303} t$ & $\frac{t}{q_{t}}=\frac{1}{k_{2} q^{2}}+\frac{t}{q e}$ & $q_{e}=\frac{1}{\beta} \operatorname{Ln}(\beta \alpha)+\frac{1}{\beta} \operatorname{In} t$ \\
\hline
\end{tabular}




\section{Effect of $\mathrm{pH}$ on the $\mathrm{MgO}$ adsorption}

The results showed (Fig. 4) that increase of $\mathrm{pH}$ to 6 lead to increase of removing CIP. Moreover, the removal percentage increased from $\mathrm{pH} 2$ to $\mathrm{pH} 6(60 \%$ to $80 \%)$. Increased removal rate at $\mathrm{pH} 6$ was related to $\mathrm{pH}_{\mathrm{zpc}}$ and $\mathrm{pK}_{\mathrm{a}}$. The level of $\mathrm{pK}_{\mathrm{a}}$ for CIP is 5.7 and the level of $\mathrm{pH}_{\mathrm{zpc}}$ nanoparticles of $\mathrm{MgO}$ is 12.4 (Kord Mostafapour et al, 2017; Tajbakhsh et al., 2014). It was related to $\mathrm{pH}_{\mathrm{zpc}}$ and $\mathrm{pK}_{\mathrm{a}}$. The point of zero charge is the point where the charge on catalyst surface is zero. In the $\mathrm{pH}$ less than $\mathrm{pH}_{\mathrm{zpc}}$, the catalyst had positive charge that increase of $\mathrm{pH}$ to 6 , Electrostatic adsorption between CIP negative ions and positive charged $\mathrm{MgO}$ nanoparticles increased, therefore, the efficiency of removal increased (Venkatesha et al., 2013; Moussavi et al., 2011).

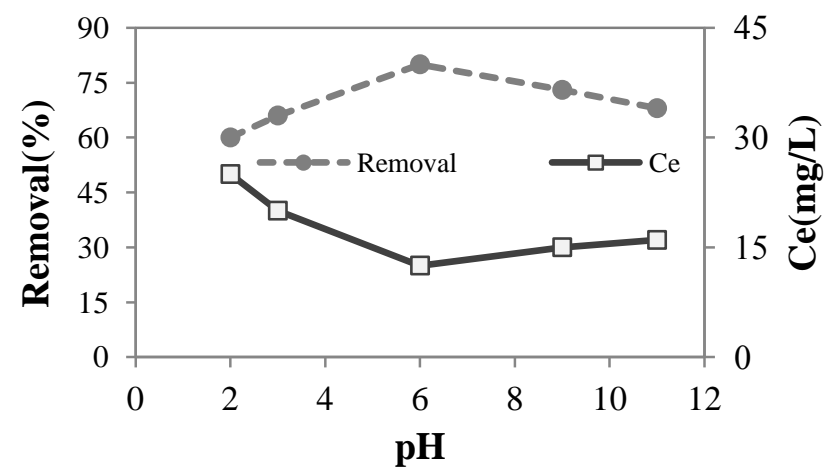

Fig.4: Effect of $\mathrm{pH}$ on percentage removal of CIP (Time: 60 min, dosage: $0.1 \mathrm{~g} / \mathrm{L}, \mathrm{CIP}$ concentration: $100 \mathrm{mg} / \mathrm{L}$ ).

\section{Effect of initial ciprofloxacin concentration}

To determine the effect of initial CIP concentration on the adsorption process the initial concentration of CIP was varied from 10 to $250 \mathrm{mg} / \mathrm{L}$ at the optimum $\mathrm{pH}$, adsorbent dose $0.1 \mathrm{~g} / \mathrm{L}$ and contact time $60 \mathrm{~min}$. As presented in Fig. 5, CIP removal efficiency decreased with increasing of initial CIP concentration. So, maximum efficiency was achieved at initial CIP concentration $10 \mathrm{mg} / \mathrm{L}(85 \%)$. The main reason was an increase of contact and collision between adsorbent and adsorbate (Moussavi et al., 2011).

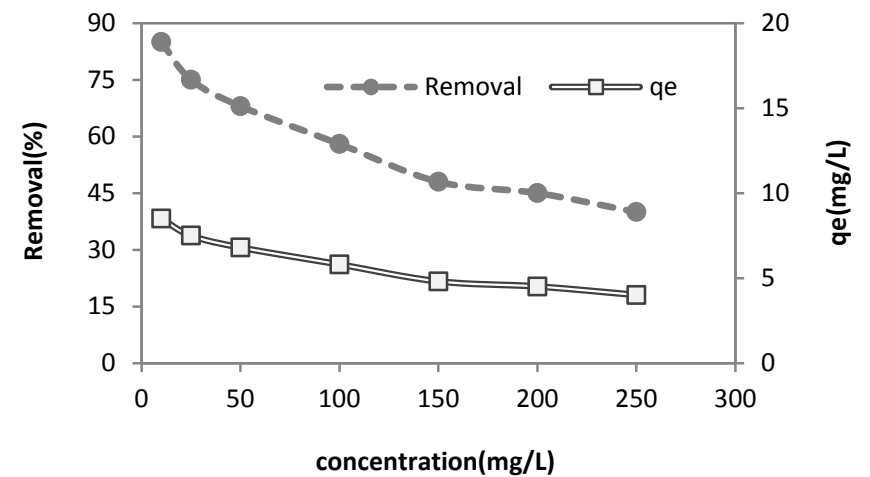

Fig. 5: Effect of initial CIP concentration on percentage removal of CIP (Time: 60 min, $\mathrm{pH}: 6$, dosage: $0.1 \mathrm{~g} / \mathrm{L}$ ).

\section{Effects of adsorbent dose on the MgO adsorption}

The Fig.6, the adsorbent concentration increased from 0.1 to $1 \mathrm{~g} / \mathrm{L}$ for improved concentration $10 \mathrm{mg} / \mathrm{L} \mathrm{CIP}$, the efficiency increased from $60 \%$ to $83 \%$; in fact the level of deletion significantly depends on active places and by increasing the dosage of nanoparticle to an appropriate level, the deletion efficiency will also be increased (Tamimi et al., 2008).

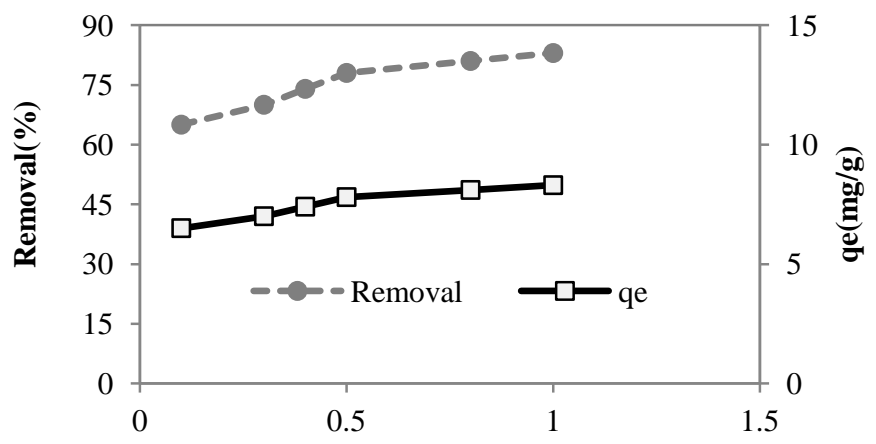

Adsorbent dose(g)

Fig. 6: Effect of adsorbent dose on percentage removal of CIP (Time: $60 \mathrm{~min}$, pH: 6, CIP concentration: $25 \mathrm{mg} / \mathrm{L}$ ).

\section{Effects of contact time on the MgO adsorption}

The efficiency of antibiotic deletion at the contact time $60 \mathrm{~min}$ and the concentration of antibiotic $(10 \mathrm{mg} / \mathrm{L})$ have increased $85 \%$ (Fig. 7). By increasing the contact time, the efficiency of antibiotic deletion will be increased. The reason for increasing the deletion efficiency at the early hours is that by passing the time the made cavity and corrosion on nanoparticle level will be expanded and so increase the cross section of adsorption and efficiency (Samadi et al., 2013). The reason for decreasing removal efficiency by enhancement of antibiotic concentration is saturation of active places of adsorption (Samadi et al., 2013; Zhang, 2017).

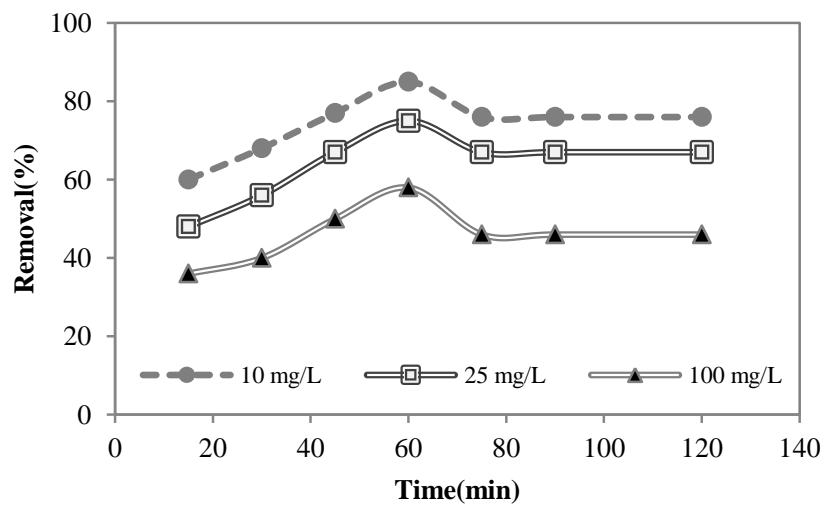

Fig. 7: Effect of time on percentage removal of CIP (pH: 6, dosage: 1g/L, CIP concentration: $25 \mathrm{mg} / \mathrm{L}$ ).

The isothermal models and adsorption kinetics are shown in Table 2 and 3.The results showed that ciprofloxacin fitted according to Langmuir isotherm model $\left(\mathrm{R}^{2}=0.96\right)$. The $\mathrm{R}^{2}$ of kinetic models suggested that the pseudo-second -order model mechanism is predominant which means the uptake process follows the pseudo second-order expression with correlation coefficients were always greater of 0.9785 . 


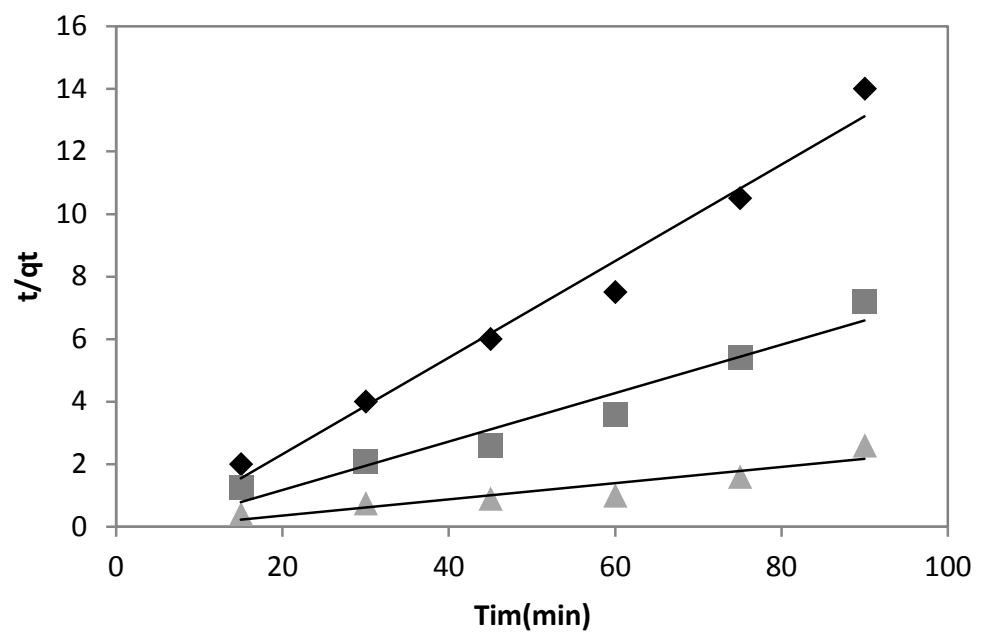

Fig.8: Kinetic isotherms pseudo-second-order

Table 2: The adsorption isotherms constants for the absorption CIP.

\begin{tabular}{|c|c|c|c|c|c|c|c|c|c|c|}
\hline \multirow[t]{2}{*}{$\mathrm{C}_{0}(\mathrm{mg} / \mathrm{L})$} & \multicolumn{4}{|c|}{ Langmuir } & \multicolumn{3}{|c|}{ Freundlich } & \multicolumn{3}{|c|}{ Tempkin } \\
\hline & $\mathrm{q}_{\mathrm{m}}$ & $\mathrm{k}_{\mathrm{L}}$ & $\mathrm{R}^{2}$ & $\mathrm{R}_{\mathrm{L}}$ & $\mathrm{n}$ & $\mathrm{k}_{\mathrm{f}}$ & $\mathrm{R}^{2}$ & $\mathrm{~B}_{\mathrm{T}}$ & $\mathrm{A}_{\mathrm{T}}$ & $\mathrm{R}^{2}$ \\
\hline 10 & 3.46 & 0.08 & 0.9613 & 0.55 & 1.8 & 39.8 & 0.93 & 0.24 & 0.129 & 0.934 \\
\hline
\end{tabular}

Table 3: The adsorption kinetic model constants for the absorption CIP

\begin{tabular}{|c|c|c|c|c|c|c|c|c|c|}
\hline \multirow[t]{2}{*}{$\mathrm{C}_{0}(\mathrm{mg} / \mathrm{L})$} & \multicolumn{3}{|c|}{ Pseudo-first order } & \multicolumn{3}{|c|}{ Pseudo-second order } & \multicolumn{3}{|c|}{ Elovich } \\
\hline & $\mathrm{K}_{1}$ & qe & $\mathrm{R}^{2}$ & $\mathrm{~K}_{2}$ & qe & $\mathrm{R}^{2}$ & $\alpha$ & $\beta$ & $\mathrm{R}^{2}$ \\
\hline 10 & 0.04 & 0.2 & 0.862 & 0.02 & 6.5 & 0.978 & 6.9 & 0.93 & 0.785 \\
\hline 25 & 0.006 & 4.48 & 0.539 & 0.006 & 12.91 & 0.947 & 14.4 & 0.41 & 0.768 \\
\hline 100 & 0.004 & 29.71 & 0.362 & 0.0006 & 38.6 & 0.859 & 146.6 & 0.19 & 0.28 \\
\hline
\end{tabular}

\section{CONCLUSION}

In this study, the adsorption of CIP onto $\mathrm{MgO}$ nanoparticles has been investigated. The results of this study indicate that optimum conditions for the operation of the $\mathrm{MgO}$ nanoparticles with CIP concentration of $10 \mathrm{mg} / \mathrm{L}, \mathrm{pH}$ of $6, \mathrm{MgO}$ dose $1 \mathrm{~g} / \mathrm{L}$ and contact time of 60 min can remove a large impact on the concentration of CIP in water. According to the results, under optimal conditions of concentration, the removal efficiency was $85 \%$.and $\mathrm{q}_{\mathrm{m}}$ of the $\mathrm{MgO}$ nanoparticles was $3.46 \mathrm{mg} / \mathrm{g}$. The process of CIP adsorption on $\mathrm{MgO}$ nanoparticles was depended on Langmuir absorption isotherm more than other isotherms. Batch kinetic experiments showed that the adsorption followed pseudosecond-order kinetic model with correlation coefficients greater than 0.978 .

\section{Financial support and sponsorship: Nil.}

Conflict of Interests: There are no conflicts of interest.

\section{REFERENCE}

Abramović B.F, Despotović V.N, Šojić D.V, Orčić D.Z, Csanádi JJ, Četojević-Simin DD.Photocatalytic degradation of the herbicide clomazone in natural water using TiO2: Kinetics, mechanism, and toxicity of degradation products. Chemosphere, 2013; 93(1):166-71.

Andreozzi R, Canterino M, Marotta R, Paxeus N. Antibiotic removal from wastewaters: the ozonation of amoxicillin. Journal of hazardous Materials, 2005; 122(3): 243-50.
Ahmadi-a S, Banach A, Kord Mostafapour F, Balarak D. Study survey of cupric oxide nanoparticles in removal efficiency of ciprofloxacin antibiotic. Desalination and Water Treatment, 2017; 88: 1-7. doi: 10.5004/dwt.2017.21362.

Ahmadi-b sh, Kord Mostafapour, F. Survey of Efficiency of Dissolved Air Flotation in. Removal Penicillin G Potassium from Aqueous Solutions British Journal of Pharmaceutical Research, 2017; 15(3), 1-11.

Ahmadi-c S., Kord Mostafapour F. Adsorptive removal of aniline from aqueous solutions by Pistacia atlantica (Baneh) shells: isotherm and kinetic studies, J. Sci. Technol. Environ. Inform, 2017; $5,327-335$

Ahmadi-d S, Kord Mostafapour F, Bazrafshan E. Removal of Aniline and from Aqueous Solutions by Coagulation/Flocculation Flotation, Chem. Sci. Int J, 2017; 18, 1-10.

Ji Y, Ferronato C, Salvador A, Yang, X, Chovelon J-M. Degradation of ciprofloxacin and sulfamethoxazole by ferrous-activated persulfate: Implications for remediation of groundwater contaminated by antibiotics. Science of the Total Environment, 2014; 472,800-8.

Jiantuan Ge, Jiuhui Qu., Ultrasonic irradiation enhanced degradation of azo dye on $\mathrm{MnO} 2$. Appl Catal B Environ, 2004; 47,133140 .

Kermani M., Bahrami Asl F., Farzadkia M., Esrafili A., Salahshur Arian S., Arfaeinia H., et al. Degradation efficiency and kinetic study of metronidazole by catalytic ozonation process in presence of mgo nanoparticles. Urmia medical journal, 2013; 24(10): 839-50.

Kord Mostafapour-a F, Ahmadi S, Balarak D, Rahdar S. Comparison of dissolved air flotation process Function for aniline and penicillin G removal from aqueous solutions, J. Hamadan Univ. Med. Sci. 2017; 82: 203-209.

Kord Mostafapour F, Bazrafshan E, Balarak D, Khoshnamvand N. Survey of Photo-catalytic degradation of ciprofloxacin antibiotic using 
copper oxide nanoparticles ( $\mathrm{UV} / \mathrm{CuO}$ ) in aqueous environment. J Rafsanjani Univ Med Sci, 2016; 15, 307-18.

Ikehata K, Jodeiri Naghashkar N, Gamal El-Din $\mathrm{M}$. Degradation of aqueous pharmaceuticals by ozonation and advanced oxidation processes: a review. Ozone: Science and Engineering, 2006; 28(6): 353-414.

Moussavi G, Alahabadi A, Yaghmaeian K, Eskandari M. Preparation. characterization and adsorption potential of the $\mathrm{NH} 4 \mathrm{Cl}$ induced activated carbon for the removal of amoxicillin antibiotic from water, Chemical Engineering Journal ,2011; 217,119-128.

Nga NK, Hong PTT, Lam TD, Huy TQ. A facile synthesis of nanostructured magnesium oxide particles for enhanced adsorption performance in reactive blue 19 removal. Journal of Colloid and Interface Science, 2013;398,210-6

Samadi MT, Kashitarash Esfahani Z, Ahangari F, Ahmadi S, Jafari J. Nickel Removal from Aqueous Environments Using Carbon Nanotubes, J. Water. Waste, 2013; 24, 38-44.

Tamimi M., Qourzal S, Barka N, Assabbane A, Ait-Ichou Y. Methomyl degradation in aqueous solutions by Fenton's reagent and the photo-Fenton system. Separation and Purification Technology, 2008; 61(1): 103-8.

Tajbakhsh M., Farhang M., Hosseini A. MgO nanoparticles as an efficient and reusable catalyst for aza-Michael reaction. J IRAN CHEM SOC, 2014;11(3),665-72.
Zhang C-L, Qiao G-L, Zhao F, Wang Y. Thermodynamic and kinetic parameters of ciprofloxacin adsorption onto modified coal fly ash from aqueous solution. Journal of Molecular Liquids,2011;163(1),53-6.

Zhang H, Wang Z, Xie X, Gao J, Zuhn J, Xie C. Comparison of chloramphenicol adsorption behavior on biochars derived from reed straws and municipal sewage sludge,2017;26,4400-4408.

Wu S, Zhao X, Li Y, Zhao C, Du Q., Sun J. et al. Adsorption of ciprofloxacin onto biocomposite fibers of graphene oxide/calcium alginate. Chemical Engineering Journal, 2013; 230: 389-95.

Venkatesha TG, Nayaka YA, Chethana BK. Adsorption of Ponceau $\mathrm{S}$ from aqueous solution by $\mathrm{MgO}$ nanoparticles. Applied Surface Science, 2013; 276: 620-7.

\section{How to cite this article:}

Khoshnamvand N, Ahmadi S, Mostafapour FK. Kinetic and Isotherm Studies on Ciprofloxacin an Adsorption using Magnesium Oxide Nanopartices. J App Pharm Sci, 2017; 7 (11): 079-083. 